\title{
Pelatihan Analisis SWOT Dan BMC Pada Asosiasi UMKM Ponorogo
}

\author{
Dhika Amalia Kurniawan ${ }^{1}$, Fajar Surya Ari A ${ }^{2}$, Lathiefa Rusli ${ }^{3}$, Rahma Yudi A ${ }^{4}$, \\ Apriliana Ika $\mathbf{K}^{5}$
}

\author{
Program Studi Manajemen, Fakultas Ekonomi \\ Universitas Darussalam Gontor ${ }^{1,2,3,4,5}$ \\ Email : dhika.amalia@unida-gontor.ac.id ${ }^{1}$
}

\begin{abstract}
The developing of business activities today add up the competition in the market, so that it requires some of specific business strategies to make the SME's survive on the existing business competition. Business has to survive on its potential, minimize its disadvantages, and increase its advantages to keep on track from the business competition. The problems faced by small and micro scale business in Ponorogo, around 75 businesses are joined in the association of SMEs, are the weaknesses of formulating strategy and the inability to describe their own business strengths, weaknesses, opportunities, and threats which need to be developed. The aims of the community service are to help the SMEs actors to develop and analyze their business strategies. Therefore, the community service's approaches are using SWOT analysis and Business Model Canvas. Furthermore, the SMEs can describe and analyze their both internal and external aspect to give some ideas in surviving and developing the existing business.
\end{abstract}

Keywords: SMEs; SWOT Analysis; BMC

\begin{abstract}
Abstrak
Berkembangnya bisnis dengan berbagai keunggulan membuat persaingan semakin ketat sehingga menuntut para pelaku bisnis untuk dapat membuat strategi khusus dalam menghadapi kompetisi bisnis. Suatu bisnis harus mampu bergerak maju dengan potensi yang dimilikinya dan meminimalisir kelemahannya hingga dapat terus berjalan dan mampu bertahan dalam persaingan yang terus berkembang. Permasalahan yang dialami oleh para pelaku usaha skala mikro di Kabupaten Ponorogo adalah lemahnya penyusunan strategi bisnis dan pengoptimalan kemampuan yang dimiliki, para pelaku UMKM merasa bingung untuk mendeskripsikan kekuatan, kelemahan, peluang, dan ancaman bisnis mereka yang perlu memerlukan strategi untuk menghadapinya. Dalam hal ini, sebanyak 75 pelaku usaha yang tergabung dalam asosiasi UMKM Ponorogo Jawa Timur. Tujuan dari pengabdian masyarakat ini adalah membantu para UMKM untuk dapat menyusun dan mengoptimalkan strategi pengembangan usahanya, sehingga perlu dianalisis dengan pendekatan SWOT. Harapan dari program pengabdian ini adalah para UMKM mampu mendeskripsikan dan menganalisis aspek internal dan eksternal agar mampu bertahan dalam persaingan bisnis. Adapun kegiatan yang akan dilakukan melalui 1) pelatihan analisis SWOT dan 2) pelatihan business model canvas (BMC).
\end{abstract}

Kata Kunci: UMKM; Analisis SWOT; BMC 


\section{Pendahuluan}

Tidak dapat dihindari dan dicegah adanya persaingan yang terus menuntut para pelaku bisnis untuk dapat berkembang, dengan menunjukkan kekuatan, keunikan serta kelebihannya agar dapat melayani konsumen lebih banyak lagi dan tentunya mampu bertahan dipasar yang ada. Dengan adanya perkembangan teknologi saat ini menjadikan bisnis semakin maju baik dari operasional perusahaannya, hingga strategi pemasaran produknya dengan cara memanfaatkan teknologi tersebut. Tentu hal ini menjadikan bisnis yang kuat semakin berkembang dan sebaliknya bisnis yang lemah semakin lemah, sehingga menjadi ketimpangan yang jauh terhadap usaha mikro kecil menengah yang pada dasarnya masih kecil, tradisional dan sulit untuk berkembang karena kurangnya berbagai faktor internal dalam bisnis tersebut. Apabila hal tersebut terus dibiarkan maka akan terjadi ketidakseimbangan dalam dunia bisnis. Untuk itu perlu pengetahuan bagi pelaku bisnis mikro kecil menengah untuk dapat menyusun strategi dalam bersaing dengan mengenali terlebih dahulu faktor internal dalam usahanya yaitu kekuatan dan kelemahan yang dimiliki usaha tersebut. Berikutnya adalah mengenali faktor eksternal yang ada disekeliling usaha yaitu peluang yang dapat dimasuki dan ancaman yang dapat merusak suatu usaha. Usaha mikro kecil menengah (UMKM) adalah suatu produktif yang berdiri sendiri, yang dilakukan oleh orang perorangan atau Badan Usaha disemua sektor ekonomi (Tambunan,2012)

Usaha ini hampir merata ada di seluruh kota, desa hingga pelosok daerah. Pelaku UMKM ini masih banyak yang sulit berkembang karena banyak faktor, seperti memilih bertahan pada posisi yang sama, kebinggungan cara untuk bisa berkembang, kurangnya pengetahuan dan pemahaman sehingga tidak mungkin bila bersaing dengan produk perusahaan skala besar yang mampu bersaing karena bantuaan teknologi yang digunakannya. Melihat hal tersebut, menjadi tugas bagi pemerintah dan pihak-pihak yang berkepentingan serta pihak akademisi untuk turut membantu mengembangkan produk sektor mikro agar mampu bersaing secara bertahap dengan produk pesaing yang ada. Diantaranya dapat dilakukan melalui berbagai strategi : 1) Pelatihan analisis SWOT. Analisis SWOT ini adalah sebuah analisa tentang faktor internal perusahaan yaitu kekuatan dan kelemahan serta menganalisis faktor ekternal perusahaan yaitu peluang dan ancaman ,untuk dapat merumuskan stategi dalam bersaing (Rangkuti, 2008). 2) Pelatihan business model canvas (BMC). BMC merupakan sebuah model bisnis dengan melakukan pemetaan bisnis dengan menggunakan 9 komponen yang terdiri dari Customer Segments, Value Proposition, Channels, Customer Relationships, Revenue Streams, Key Resources, Key Activities, Key Partnerships, dan Cost Structure (Osterwalder, 2013). Kedua kegiatan tersebut saling berkesinambungan untuk dapat menyusun strategi pengembangan bisnis masing-masing pelaku usaha dengan dilihat dari kekuatan yang perlu dimaksimalkan, kelemahan yang perlu disusun strateginya, peluang yang perlu untuk dimanfaatkan serta ancaman pesaing yang perlu untuk disiasati.

Konsep usaha kecil itu sendiri sesungguhnya, dari 48,9 juta usaha kecil di Indonesia, hanya 1 juta unit lebih yang benar-benar dapat disebut sebagai pengusaha kecil. Koperasi pun hanya 80 ribu lebih, lebih dari 47,50 juta pengusaha sesungguhnya dikategorikan sebagai usaha mikro (Sari, 2016). Dengan demikian, bila kita berbicara tentang UMKM perlu di ingat bahwa sebetulnya kebanyakan usaha yang kita bahas itu bersifat sangat kecil. Sampai saat ini masih terdapat perbedaan mengenai kriteria pengusaha kecil baik yang ada dikalangan perbankan, lembaga terkait, biro statistik (BPS), maupun menurut kamar dagang dan industri Indonesia (KADIN). Perbedaan kriteria tersebut adalah Bank Indonesia. Suatu perusahaan atau perorangan yang 
mempunyai total assets maksimal Rp. 600 juta tidak termasuk rumah dan tanah yang ditempati. Untuk Departemen Perindustrian kriteria usaha kecil sama dengan Bank Indonesia. Biro Pusat Statistik (BPS); Usaha rumah tangga mempunyai : $1-5$ tenaga kerja, Usaha kecil mempunyai : 6-19 tenaga kerja, Usaha menengah mempunyai : 20-99 tenaga kerja (BPS, 2017). Kamar Dagang Industri Indonesia (KADIN); Industri yang mempunyai total assets maksimal Rp.600 juta termasuk rumah dan tanah yang ditempati dengan jumlah tenaga kerja dibawah 250 orang. Departemen Keuangan; Suatu badan usaha atau perorangan yang mempunyai assets setinggi-tingginya Rp. 300 juta atau yang mempunyai omset penjualannya maksimal Rp. 300 juta per tahun (Rachbini, 2013).

Sebagai perbandingan dikemukakan pula beberapa kriteria usaha kecil beberapa Negara berkembang seperti India, Thailand dan Philipina. India, Industri yang memiliki pabrik dan mesin-mesin beserta perlengkapannya dengan fixed assets maksimal Rupe 2.500.000 atau sekitar Rp. 496,4 juta. Thailand Industri yang memiliki fixed assets maksimal Bath 2.000.000 atau sekitar Rp. 438,1 juta. Philipina Usaha rumah tangga industri adalah yang nilai fixed assets kurang dari Pesos 100.000 atau sekitar Rp. 16 juta. Small industry adalah yang nilai fixed assetsnya antara Pesos $100.000 \mathrm{~s} / \mathrm{d}$ 1.000 .000 atau sekitar Rp. 160,8 juta.

Usaha berskala mikro, kecil dan menengah dalam arti yang sempit seringkali dipahami sebagai suatu kegiatan usaha yang memiliki jumlah tenaga kerja dan atau assets yang relatif kecil meliputi evaluasi dari bidang manajemen seperti pemasaran (Suhartini, 2012). Bila hanya komponen ini dijadikan sebagai patokan dalam menentukan besar kecilnya skala usaha maka banyak bias yang terjadi, sebagai contoh sebuah perusahaan yang memperkejakan 50 orang karyawan di Amerika Serikat di kategorikan sebagai perusahaa kecil (relatif terhadap ukuran ekonomi Amerika Serikat). Sementara itu untuk ukuran yang sama, sebuah perusahaan di Bolivia tidak lagi masuk dalam kategori usaha kecil. Dengan demikian, diperlukan komponen atau karakteristik lain dalam melakukan penilaian analis SWOT dan penyusunan model bisnis untuk usaha kecil dan menengah

Di Ponorogo Jawa Timur, banyak pelaku usaha skala mikro yang menghasilkan produk beraneka ragam dan tergabung dalam asosiasi UMKM Ponorogo. Permasalahan secara umum para pelaku UMKM Ponorogo adalah kesulitan dalam merancang strategi pengembangan usaha. Terbukti selama puluhan tahun usaha mereka berjalan masih dalam tahap yang sama, belum menunjukkan tahap perkembangan. Apalagi dari tahun ke tahun dunia bisnis terus mengalami kemajuan baik dalam sistem, inovasi, teknologi, pemasaran hingga mampu menempus pasar asing sekalipun bisnis tersebut baru dibangun atau baru berjalan.

Membuat Analisa SWOT memungkinkan kelompok pengarah usaha kecil menengah untuk menghasilkan pemahaman kolektif tentang ide bisnis usaha kecil menengah, bagaimana usaha kecil menengah di Ponorogo dapat mengartikulasikan evaluasi usaha dan bagaimana usaha kecil menengah akan berkembang lebih baik. Menulis analisis SWOT melibatkan peramalan apa yang dapat terjadi dalam lingkungan di mana usaha menengah kecil yang beroperasi, sehingga mendorong usaha kecil menengah di Ponorogo untuk mempertimbangkan bagaimana mereka mungkin perlu beradaptasi dengan perubahan keadaan, melindungi usaha kecil menengah terhadap risiko, dan mengambil keuntungan dari setiap peluang yang timbul. Sebuah analisis SWOT menjadi kunci dalam menunjukkan kelangsungan hidup apa yang diusulkan, itulah sebabnya penyandang dana atau investor biasanya akan meminta rencana bisnis sebelum mereka memutuskan apakah untuk mendukung pengembangan usaha masing-masing di Ponorogo. Selain mem- 
bantu usaha kecil menengah untuk menunjukkan kelangsungan hidup ide usaha kecil menengah dan mendukung evaluasi usaha kecil menengah kepada penyandang dana dan investor, Analisa SWOT ini membantu orang yang berbeda (stakeholder) yang terlibat dalam usaha kecil menengah usaha untuk menyatukan ide usaha kecil dan krusial, menyediakan informasi keunggulan, kelemahan, peluang, dan ancaman usaha kecil menengah dengan peta rute untuk tujuan akhir bisnis kecil menengah dan serangkaian tolok ukur untuk mengukur kemajuan bisnis menengah kecil di sepanjang jalan. Oleh karena itu, pentingnya perencanaan bisnis yang efektif tidak dapat dibesar-besarkan: jika usaha kecil menengah gagal untuk merencanakan, usaha kecil menengah bisa merencanakan untuk gagal (Rangkuti, 2002).

Beberapa masalah yang dihadapi oleh mitra IKM dan dengan melihat urgensi dari progam pengabdian masyarakat ini, maka solusi yang dapat ditawarkan dalam kegiatan ini adalah sebagai berikut :

Tabel 1. Pemetaan Masalah dan Solusi

\begin{tabular}{|c|c|}
\hline Permasalahan & Solusi yang ditawarkan \\
\hline \multirow{3}{*}{$\begin{array}{l}\text { Pelaku UMKM } \\
\text { Ponorogo belum } \\
\text { dapat berkembang } \\
\text { karena kurangnya } \\
\text { pengetahuan } \\
\text { tentang cara } \\
\text { menyusun strategi } \\
\text { dengan } \\
\text { memanfaatkan } \\
\text { peluang dan } \\
\text { kekuatan yang ada } \\
\text { dalam usahanya }\end{array}$} & $\begin{array}{l}\text { Memberikan pelatihan } \\
\text { kepada pelaku usaha } \\
\text { UMKM Ponorogo untuk } \\
\text { dapat membuat deskripsi } \\
\text { usahanya dengan analisis } \\
\text { kekuatan yang dimiliki, } \\
\text { kelemahan yang } \\
\text { dihadapi, peluang yang } \\
\text { dapat dimasuki dan } \\
\text { ancaman lingkunagn } \\
\text { bisnis/ usaha yang } \\
\text { dihadapi }\end{array}$ \\
\hline & $\begin{array}{l}\text { Memberikan pelatihan } \\
\text { kepada pelaku usaha } \\
\text { UMKM Ponorogo untuk } \\
\text { melakukan analisis usaha } \\
\text { dengan menggunakan } \\
\text { analisis business model } \\
\text { canvas } 9 \text { komponen }\end{array}$ \\
\hline & $\begin{array}{l}\text { Memberikan } \\
\text { pendampingan strategi } \\
\text { yang akan digunakan } \\
\text { untuk mengembangkan } \\
\text { usaha para UMKM } \\
\text { Ponorogo }\end{array}$ \\
\hline
\end{tabular}

Sumber : data diolah, 2020
Dengan adanya permasalahan tersebut, maka kegiatan pengabdian kepada masyarakat ini bertujuan untuk membantu pelaku UMKM yang tergabung dalam asosiasi UMKM Ponorogo untuk dapat menganalisis usahanya dari segi eksternal dan internal, selain itu juga mampu melakukan analisis business model canvas (BMC) untuk dapat mengetahui aspekaspek yang dimiliki dalam operasional bisnisnya, sehingga harapannya para UMKM dapat menyusun strategi usahanya untuk dapat berkembang semakin maju menghadapi tantangan-tantangan bisnis yang ada dengan memanfaatkan kekuatan dan peluang yang ada, dan meminimalisir kelemahan serta ancaman yang ada.

\section{Pelaksanaan dan Metode}

Metode yang digunakan dalam kegiatan pengabdian kepada masyarakat ini adalah memberikan pengetahuan dan sosialisasi kepada pelaku UMKM Ponorogo yang berada dalam asosiasi UMKM Ponorogo tentang pentingnya pengembangan bisnis dan strategi yang dapat dilakukannya. Dalam mendukung hal tersebut maka yang perlu dilakukan adalah 1). Melakukan pendeskripsian tentang faktor internal usaha UMKM yaitu kekuatan serta kelemahan yang dimiliki, kemudian juga melakukan deskripsi tentang faktor eksternal dalam usaha yaitu peluang dan ancaman dalam bisnis. Berikutnya 2). Melakukan analisis usaha menggunakan salah satu model bisnis untuk dapat mengetahui aspek-aspek operasional sebuah usaha.

Tahapan awal meliputi kegiatan persiapan yang dilaksanakan dengan melakukan sosialisasi kepada para anggota asosiasi UMKM Ponorogo. Sosialisasi ini berisi tentang pengetahuan dalam meningkatkan usaha dengan berbagai 
strategi berdasarkan kekuatan dan peluang yang dimiliki usaha masing-masing. Sebelum melakukan sosialisasi, kami telah mengamati dan melakukan survey terhadap para anggota asosiasi UMKM Ponorogo, yang mana usahanya telah dijalankan dalam waktu yang cukup lama, namun kenyataan yang terjadi saat ini dari hasil pengamatan adalah usaha para UMKM masih dalam tahap awal, masih sederhana dalam berbagai aspek, belum menunjukkan perkembangan yang menonjol dari segi operasional dan sederhana dalam kegiatan yang dilakukan sehari-hari. Dengan kondisi tersebut, menurut kami perlu dibantu untuk melakukan perbaikan sehingga akan mampu memberikan kontribusi bagi perkembangan usaha para anggota asosiasi UMKM di Ponorogo Jawa Timur.

Adapun tahap pelaksanaan antara lain dengan melakukan pelatihan analisis terhadap usaha masing-masing UMKM dengan menggunakan analisis faktor internal dan eksternal usahanya. Tahap kedua adalah melakukan analisis bisnis menggunakan teori business model canvas (BMC) yang terdiri dari Customer Segments, Value Proposition, Channels, Customer Relationships, Revenue Streams, Key Resources, Key Activities, Key Partnerships, dan Cost Structure.

Berikut adalah contoh kerangka kerja analisis SWOT: dari kelompok UKM, membangun sub-keunggulan, kelemahan, peluang, ancaman yang terdiri dari tiga sampai lima indikator. Untuk sub-SWOT masing-masing, menetapkan informasi berdasarkan interaksi antar peserta, seberapa sering perspektif antar peserta juga membantu penentuan indikatornya. Peserta kemudian harus membuat kerangka pengambilan keputusan yaitu daftar semua indikator yang membutuhkan pandangan dari fasilitator/pemateri. Antara pemateri dan peserta kemudian merancang kesem- patan problem-solving untuk mendiskusikan dan membuat keputusan tentang aspek kunci dari analisis SWOT usahanya. Menghasilkan draf dokumen pertama analisis SWOT bisnis masing-masing berdasarkan materi yang dihasilkan sebagai hasil pengambilan keputusan, ditambah masukan tambahan jika memungkinkan untuk menunjang hasil analisis SWOT yang dilakukan (Rangkuti, 2010).

\section{Hasil dan Pembahasan}

Permasalahan mitra anggota asosiasi UMKM Ponorogo adalah dalam hal pengembangan usaha. Hal ini disebabkan karena para UMKM merasa binggung bagaimana cara pengembangan usahanya dan dapat dimulai dari sesi yang mana, sehingga tahap pertama adalah kami melakukan sosialisasi pada anggota asosiasi UMKM Ponorogo untuk dapat melakukan perubahan usaha menjadi lebih maju lagi dengan mempelajari dan mengetahui sisi yang dapat dikembangkan dari usaha yang dijalankannya.

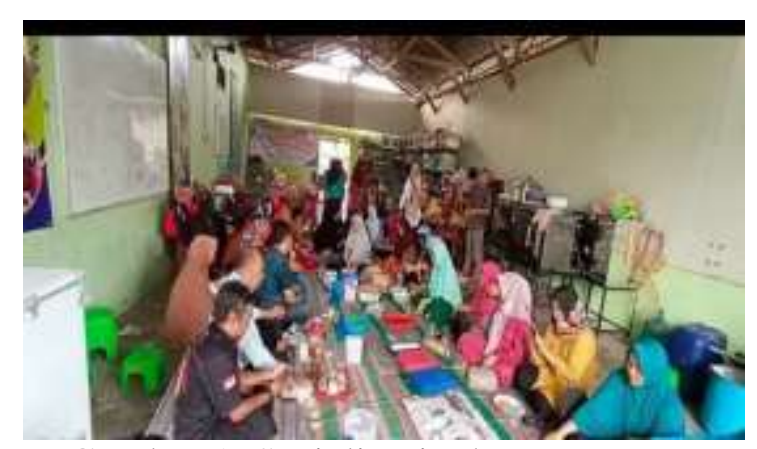

Gambar 1. Sosialisasi tahap pertama

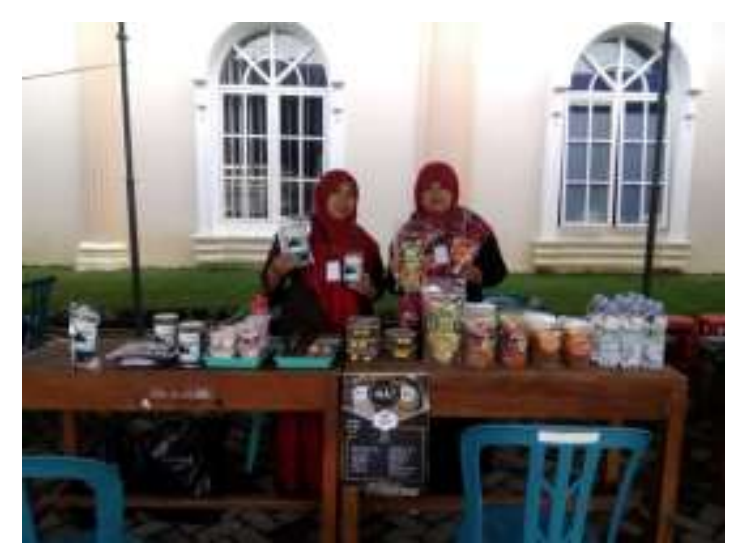

3.a) 


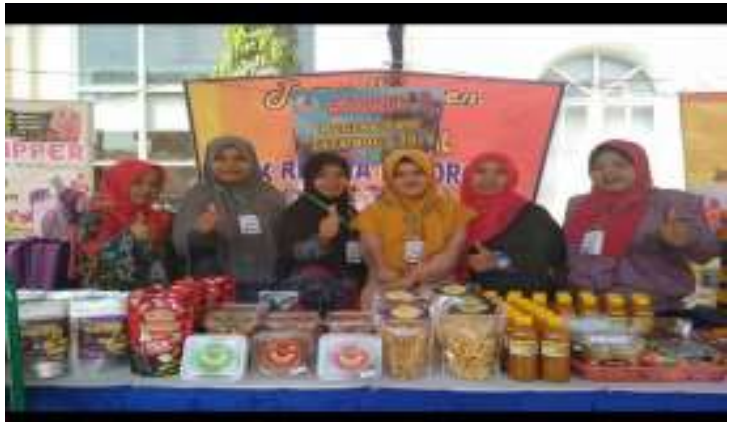

3.b)

Gambar 3.a dan 3.b UMKM masih berdagang berpindah mengikuti bazar dan pameran

Melihat permasalahan tersebut, kami membantu dengan memberikan wawasan terlebih dahulu tentang pentingnya pengembangan usaha mikro dalam menghadapi tantangan global. Pengembangan usaha dapat dimulai dengan mengetahui kemampuan suatu usaha serta peluang yang dapat dimanfatkan.

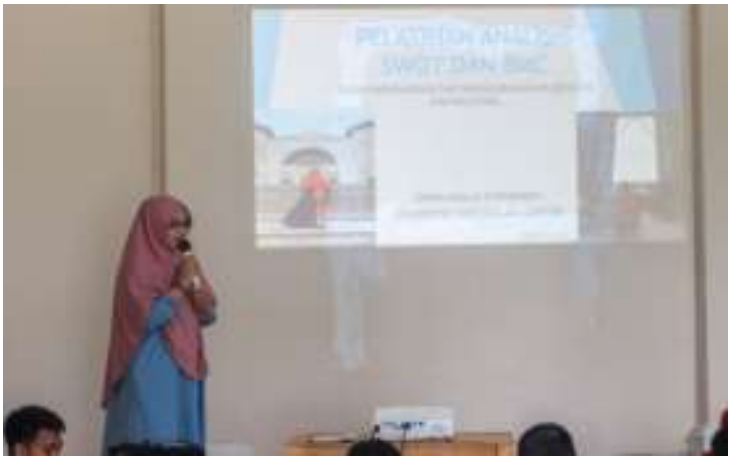

Gambar 4. Kegiatan Pelatihan 1

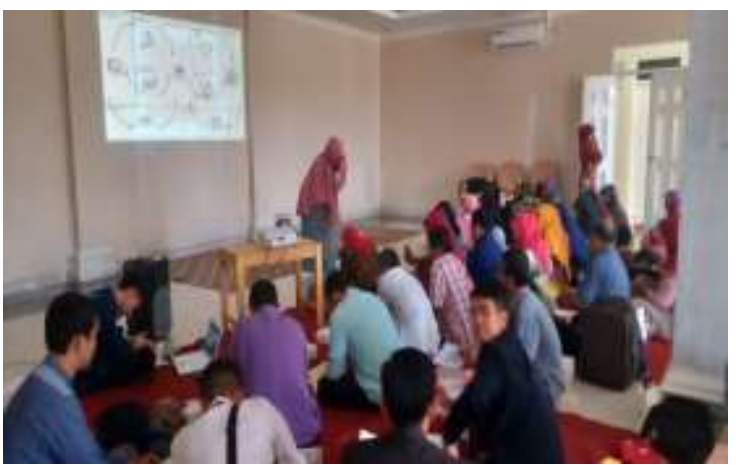

Gambar 5. Kegiatan Pelatihan 2

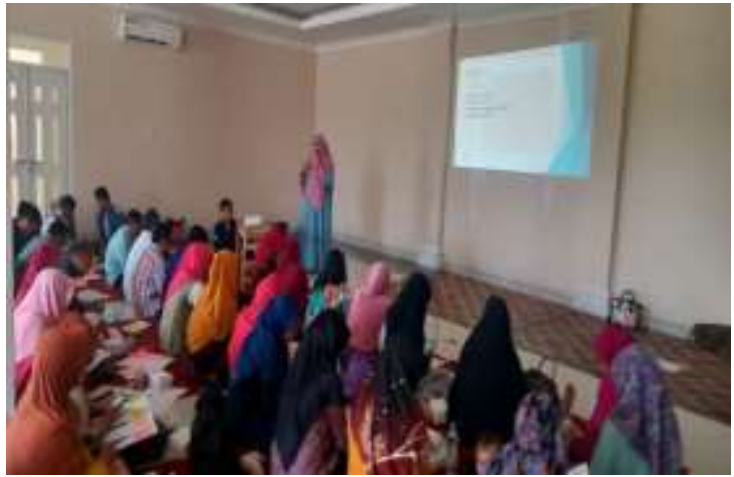

Gambar 6. Kegiatan Pelatihan 3

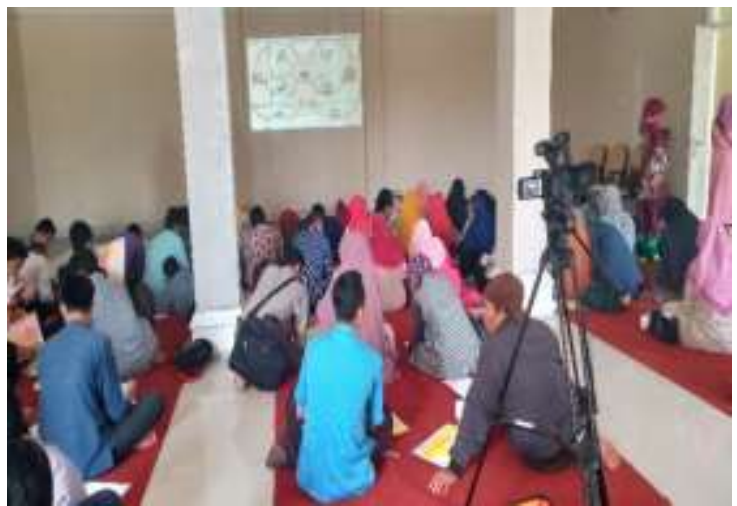

Gambar 7. Kegiatan pelatihan 4

Adapun pelatihan yang diberikan adalah melakukan analisis usaha masing para UMKM dengan menuliskan kekuatan dari usaha yang dikelola para UMKM Ponorogo. Setelah itu adalah menuliskan kelemahan usaha masing-masing, dan dilanjutkan menuliskan peluang kedepan yang dapat dimasuki walaupun saat ini masih belum mampu untuk melakukannya karena berbagai faktor kelemahan yang dimiliki. Terakhir adalah menuliskan ancaman-ancaman yang dihadapi dari usaha yang saat ini dijalankannya.

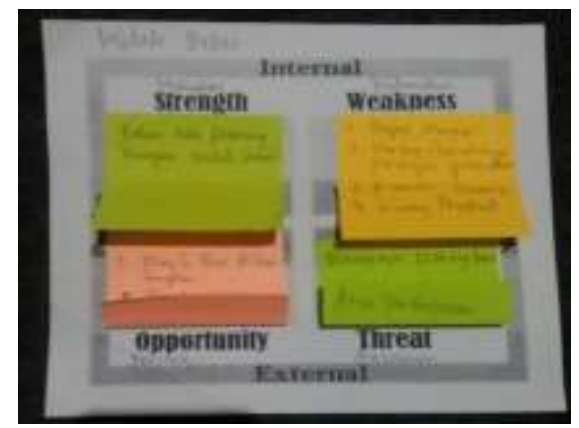

Gambar 8. Penggunaan Alat Analisis SWOT 


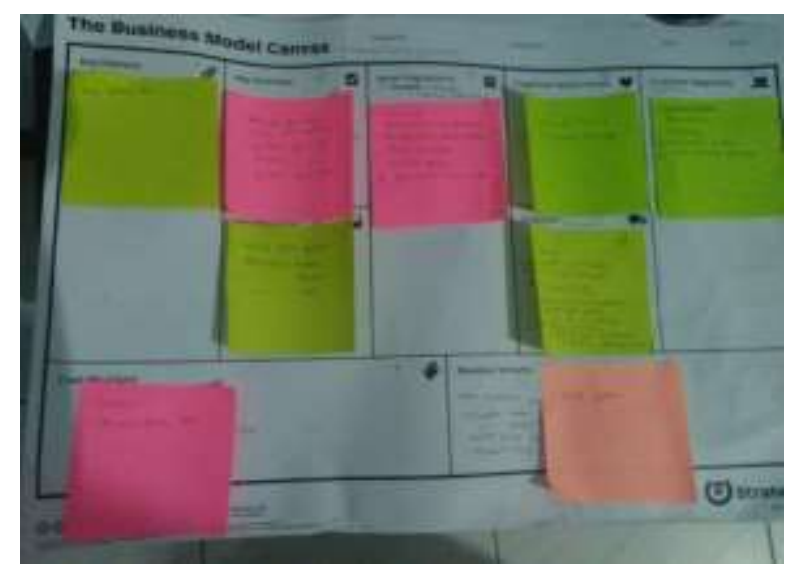

Gambar 9. Penggunaan Alat Analisis $\mathrm{BMC}$

Setelah para UMKM mampu mendeskripsikan usahanya dengan 4 komponen analisis, selanjutnya adalah memberikan pelatihan kepada mitra IKM tentang cara melakukan analisis usaha menggunakan teori business model canvas (BMC). Model bisnis ini digunakan untuk membantu pelaku usaha agar dapat memetakan usahanya dari awal hingga akhir dan jelas dalam operasionalnya, sehingga dapat mengambil keputusan kedepannya untuk berkembang lebih maju dari kondisi yang ada saat ini. Adapun pelaku UMKM diberikan pelatihan untuk menganalisis antaralain :

1. Customer Segments: para UMKM diminta untuk memetakan konsumen utama yang dilayani dari bisnisnya saat ini.

2. Value Proposition: para UMKM diminta untuk melakukan analisis value/nilai/manfaat/kelebihan/keunikan berdasarkan usaha masing-masing.

3. Channels: UMKM diminta untuk menuliskan saluran distribusi yang digunakannya untuk dapat memasarkan produknya dan menjangkau konsumennya.

4. Customer Relationships: Revenue Streams: UMKM dilatih untuk menuliskan cara mereka dalam menjalin hubungan dengan konsumen atau pelanggannya. Apakah mereka memperlakukan semua konsumen secara sama atau mereka memiliki program khusus untuk para pelanggannya.

5. Key Resources: Para UMKM dilatih untuk mendeskripsikan sumber-sumber daya yang mereka miliki yang menunjang operasional usahanya.

6. Key Activities: UMKM diminta untuk menuliskan aktifitas-aktifitas yang mereka lakukan dalam usahanya misalnya dari proses pembuatan produknya, pemasarannya atau aktifitas lain yang berada dalam lingkup usahanya.

7. Key Partnerships: UMKM diminta untuk menuliskan pihak-pihak yang membantunya dalam membuat atau memasok dan pendistribusikan produknya ke konsumen.

8. Cost Structure: UMKM dilatih untuk dapat menuliskan seluruh biaya yang diperlukan dalam operasional bisnisnya, diantaranya misalnya adalah biaya bahan baku, tenaga kerja, biaya pemasaran, biaya listrik, air, pajak dan biaya lainnya.

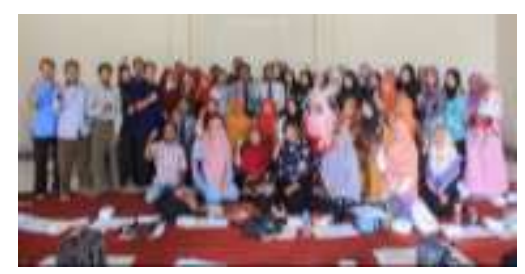

Gambar 10. Hasil Pelatihan Analisis SWOT dan BMC 1

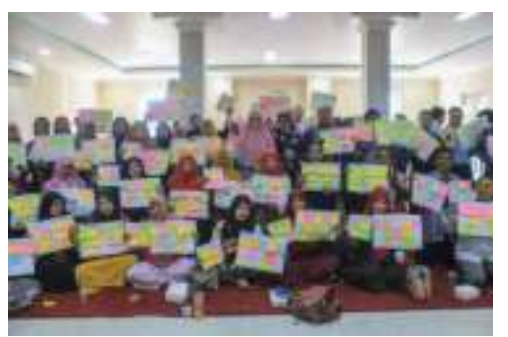

Gambar 11. Hasil Pelatihan Analisis SWOT danBMC 2 
Setelah adanya pelatihan tersebut hasilnya adalah para UMKM dapat mengetahui aspek yang dapat dikembangkan dari 9 komponen yang telah meraka tuliskan dari usaha masing-masing UMKM dengan melihat dari hasil analisis SWOT dan analisis BMC maka rumusan strategi pengembangan usaha telah dapat tersusun untuk dijadikan pedoman langkah kedepan dalam pengembangan usaha asosiasi UMKM.

Tidak ada satu standar baku format laporan atau lembar hasil analisis SWOT maupun patokan standar pada berapa banyak indikator keunggulan, kelemahan, peluang, dan ancaman suatu bisnis (Rangkuti, 2010). Peserta UKM di Ponorogo ke depan harus selalu mencoba untuk membuat lebih ringkas dan dilakukan terjadwal misalnya setahun sekali untuk menentukan langkah ke depan yang tepat sasaran sesuai dengan profil bisnisnya. Ada beberapa aspek yang harus selalu dimasukkan dalam hasil pendampingan analisis SWOT:

1. Indikator keunggulan, kelemahan, peluang, dan ancaman adalah berdasarkan apa yang masing-masing UKM di Ponorogo telah tercapai.

2. Apa latar belakang bisnis ini dikembangkan dan untuk siapa pelanggan yang diprioritaskan serta bagaimana cara kerja bisnis dalam menarik komunitas pelanggan

3. Keterkaitan antara produk, layanan pelanggan dan kegiatan bisnis yang sesuai berdasarkan manfaat apa yang akan diperoleh oleh masyarakat luas

4. adanya bisnis yang memiliki konsep/ produk / pelanggan yang sama. Hal ini menjadi salah satu pesaing bisnis masing-masing. Bagaimana profil pesaing dan apa kekuatan - kelemahan pesaing dibandingkan dengan model bisnis masing-masing UKM di Ponorogo.

5. Modal kerja yang dibutuhkan untuk mengembangkan bisnis: Berapa banyak orang yang akan dibutuhkan? Apa jenis fasilitas yang mungkin dibutuhkan?
Berapa biayanya? Dari mana keuangan ini akan berasal? Bagaimana nantinya mendapatkan investasi.

6. Pendapatan Anda: Berapa banyak produk atau jasa yang bisa masingmasing UKM Jual? Berapa taksiran pendapatan masing-masing usaha ke depan? Bagaimana akan mendapatkan pesanan kembali / berikutnya?

7. Penetapan target masing-masing bisnis, output dan hasil yang ingin dicapai oleh masing masing bisnis yang dimiliki.

\section{Penutup}

\section{Simpulan}

Hasil dari sosialisasi dan pendampingan mitra UMKM dalam strategi pengembangan usaha mikro melalui pelatihan analisis SWOT dan Bussiness Model Canvas (BMC) pada anggota asosiasi UMKM Ponorogo adalah para UMKM mampu mengetahui dan mendeskripsikan usahanya dari segi internal yaitu kekuatan dan kelemahan usaha, selanjutnya adalah mampu mendeskripsikan faktor eksternal usahanya yaitu peluang dan ancaman yang dihadapi usaha. Selain itu para UMKM saat ini telah mampu melakukan analisis tentang operasional usahanya menggunakan papan BMC.

\section{Saran}

Dari pelatihan tersebut sehingga para UMKM mengetahui peluang usaha yang dapat mereka kembangkan dimasa sekarang dan masa depan, dengan memaksimalkan kelebihan-kelebihan yang ada saat ini untuk dapat membentuk ciri khas usaha yang mereka bangun ditengah persaingan yang ada saat ini, tentu dengan melihat pesaing yang ada dan mulai memanfaatkan teknologi dalam usahanya, membuat branding usaha UMKM, dan merubah pola sederhana dalam pemasaran menjadi pola yang lebih modern sehingga mampu menarik konsumen dan pasar yang lebih luas lagi. 


\section{Daftar Pustaka}

Badan Pusat Statistik. 2017. Kendala Pemberdayaan Usaha Mikro Kecil Menengah 2015. (Online), https://www.bps.go.id/index, diakses pada tanggal 03 Maret 2020 Rachbini, D. 2013. Lembaga Pengkajian, Penelitian, dan Pengembangan Ekonomi (LP3I) Kamar Dagang dan Industri (Kadin) Indonesia. (Online), www.republika.co.id, diakses pada tanggal 03 Maret 2020

Osterwalder, A \& Pigneur, Y. 2013. Business Model Generation. Jakarta: PT Elex Media Komputindo

Rangkuti, F. 2002. Analisis SWOT Teknik Membedah Kasus Bisnis. Jakarta: PT. Gramedia Pustaka Utama

Rangkuti, F. 2008. The Power of Brands, Cetakan Ketiga. Jakarta: Gramedia Pustaka Utama.

Rangkuti, F. 2010. SWOT Balanced Scorecard. Jakarta: PT. Gramedia Pustaka. Utama Rangkuti, Freddy. 2013. Teknik Membedah Kasus Bisnis Analisis SWOT Cara. Perhitungan Bobot, Rating, dan OCAI. Jakarta: PT. Gramedia Pustaka Utama

Sari, M, Farliani, O, Intani dan Jaeroni. 2016. Profil Bisnis UMKM. Departemen Pengembangan UMKM (DPUM) Bank Indonesia. (Online),

https://www.bi.go.id/id/umkm/pen elitian/nasional/kajian/Pages/Profil -Bisnis-UMKM.aspx, diakses pada tanggal 03 Maret 2020

Suhartini. 2012. Analisa SWOT Dalam Menentukan Strategi Pemasaran Pada Perusahaan. Jurnal Matriks. Vol. XII. No. 2. ISSN: $1693-5128$. Gresik: Jurusan Teknik Industri. Universitas Muhammadiyah Gresik. 